\title{
Author Correction: Towards an arthritis flare- responsive drug delivery system
}

Nitin Joshi,2,3, Jing Yan ${ }^{3,4}$, Seth Levy 3,4, Sachin Bhagchandani', Kai V. Slaughter ${ }^{1}$, Nicholas E. Sherman', Julian Amirault ${ }^{1}$, Yufeng Wang ${ }^{1}$, Logan Riegel ${ }^{1}$, Xueyin He ${ }^{1}$, Tan Shi Rui ${ }^{1}$, Michael Valic ${ }^{1}$, Praveen K. Vemula ${ }^{1,2,3,6}$, Oscar R. Miranda 1,2,3, Oren Levy 1,2,3, Ellen M. Gravallese ${ }^{5}$, Antonios O. Aliprantis ${ }^{3,4,7}$, Joerg Ermann (i) ${ }^{3,4} \&$ Jeffrey M. Karp ${ }^{1,2,3}$

Correction to: Nature Communications https://doi.org/10.1038/s41467-018-03691-1, published online 03 April 2018.

In the original version of this Article, financial support was not fully acknowledged. The PDF and HTML versions of the Article have now been corrected to include support from the National Football League Players Association.

Published online: 11 May 2018

\begin{abstract}
(c) (i) Open Access This article is licensed under a Creative Commons Attribution 4.0 International License, which permits use, sharing, adaptation, distribution and reproduction in any medium or format, as long as you give appropriate credit to the original author(s) and the source, provide a link to the Creative Commons license, and indicate if changes were made. The images or other third party material in this article are included in the article's Creative Commons license, unless indicated otherwise in a credit line to the material. If material is not included in the article's Creative Commons license and your intended use is not permitted by statutory regulation or exceeds the permitted use, you will need to obtain permission directly from the copyright holder. To view a copy of this license, visit http://creativecommons.org/licenses/by/4.0/.
\end{abstract}

(C) The Author(s) 2018

\footnotetext{
${ }^{1}$ Center for Nanomedicine and Division of Engineering in Medicine, Department of Medicine, Brigham and Women's Hospital, 02115 Boston, MA, USA ${ }^{2}$ Harvard-Massachusetts Institute of Technology Division of Health Sciences and Technology, Massachusetts Institute of Technology, 02139 Cambridge, MA, USA. ${ }^{3}$ Harvard Medical School, 02115 Boston, MA, USA. ${ }^{4}$ Division of Rheumatology, Immunology and Allergy, Department of Medicine, Brigham and Women's Hospital, 02115 Boston, MA, USA. ${ }^{5}$ Division of Rheumatology, Department of Medicine, University of Massachusetts Medical School, MA 01605 Worcester, USA. ${ }^{6}$ Present address: Institute for Stem Cell Biology and Regenerative Medicine (inStem), UAS-GKVK post, Bellary Road, 560065 Bangalore, India. ${ }^{7}$ Present address: Merck Research Laboratories, 33 Ave Louis Pasteur, 02115 Boston, MA, USA. These authors contributed equally: Nitin Joshi, Jing Yan, Seth Levy. Correspondence and requests for materials should be addressed to J.E. (email: jermann@bwh.harvard.edu) or to J.M.K. (email: jmkarp@bwh.harvard.edu)
} 